\title{
Processes of Enhancing the Intelligence of Learning Organizations on the Basis of Competence Centers
}

\author{
Tomasz Sitek and Artur Ziólkowski \\ Gdańsk University of Technology \\ Narutowicza 11/12, 80-233 Gdansk, Poland \\ cross $^{\text {ref }}$ http://dx.doi.org/10.5755/j01.ss.85.3.8415
}

\begin{abstract}
The process of organizational learning and proper knowledge management became today one of the major challenges for the organization acting in the knowledgebased economy. According to the observations of the authors of this paper the demand for formalization of knowledge management processes and organizational learning is particularly evident in research institutions, established either by the universities, or the companies.

The goal of this article is to present the best practices related to the management of an exemplary learning organization. The authors describe the research and development competence center established by the Gdańsk University of Technology and IBM (called CAS, Centre of Advanced Studies). Such type of unit is supposed to improve the knowledge of all cooperating entities and improve the quality and efficiency of the existing processes (projects). This leads to an overall enhancement of intelligence throughout the organization - for both CAS and cooperating entities as well. The authors' experience gathered during the number of $R \& D$ projects allows claiming that building an open collaboration environment for scientists and business representatives within the framework of joint projects can be simply an effective solution.
\end{abstract}

The authors try to show the mechanisms, procedures and decisions taken in the creation of such a center, which lead to an overall strengthening of learning organization's intelligence.

Keywords: knowledge management, project management, competence centers, IT organizations, organizational learning.

\section{Introduction: competence centers in the knowledge-based economy}

The first major scientific study in the field of the knowledge-based economy was a report developed by the OECD in 1996. It emphasized the idea that knowledge has become the most important strategic resource. The OECD report contributed to the fact that the notion of the knowledge-based economy defined therein became a widely used term at the end of the twentieth century. The knowledge-based economy was described as 'an economy directly based on the production, distribution and use of knowledge and information.' (Organization for Economic, 1996).

Currently, this concept has two main meanings. In the first case, the use of the term 'knowledge-based economy' has been accepted in reference to specific economies (or their groups) in which knowledge plays a significant role. In the latter case, it refers to a set of concepts, also called a doctrine, emphasizing and promoting modern factors of economic growth and the development of civilization, such as technical and organizational innovations, education, the ability to perform under changing conditions, and other elements of human knowledge. According to this approach, a knowledge-based economy can be regarded also as a doctrine which is the paradigm of a broadly understood methodology of science (Madej, 2006).

In a knowledge-based economy, the position of an organization is determined mainly in terms of intangible resources. Such resources have three essential features which fundamentally distinguish them from material resources (Obłój, 1985):

- They can be used simultaneously in many places and do not have to be associated with the execution of a specific task in a specific location (such as a machine),

- They do not depreciate during use; on the contrary, they mostly increase in value; unlike material resources they do not lose capital,

- Material resources can be bought and sold always and everywhere. In contrast, intangible resources take a long time to achieve in an enterprise and its environment. It is difficult to trade with them.

Hence, contemporary organizations, particularly those active in the field of high technology, strive to make the best use of the potential of their intangible resources, especially knowledge. The increasing importance of knowledge for the functioning of an organization at the same time resulted in the increase in formal (and informal) ways of knowledge management. This need is addressed by the process of so-called organizational learning. According to D. Nixon (Zgrzywa-Ziemiak and Kamiński, 2009), this refers to the intentional use of learning at the level of an individual and a group, and the system of continuous transformation of an organization in a direction which will ensure the increased satisfaction of its 
shareholders (this includes both adaptive and innovative learning). D. R. Schwandt sees organizational learning in a slightly different manner - as a 'system of actions, actors, symbols and processes which enable an organization to transform information into valuable knowledge, which in turn increases the long-term adaptability of the organization.' (Orłowski and Sitek, 2010). Thus the concept of a learning organization appears, which by some authors is referred to also as an intelligent organization (this term is also adopted in this paper).

The challenges of a dynamic economic environment coupled with a constant increase in project activity (characterised by high risk) require, from today's organizations, not only proper structuring of the knowledge exploitation processes, but also intensive searching (acquiring?) of appropriate knowledge (adequate for ongoing activities, such as projects) both within their own organization and among their cooperating partners. The evidence of the increased intensity of such processes of unifying (sharing) knowledge is the growing increase in applying so-called agile approaches in IT organizations, where project teams include the representatives of the supplier as well as the client, all focused on the project goals.

Therefore, it should be emphasized that the process of organizational learning and proper knowledge management in an organization is one of the major challenges for the functioning of organizations in the knowledge-based economy. This need for the formalization of knowledge management processes and the processes of organizational learning is particularly visible in research institutions, appointed by both universities as well as businesses. The purpose of this paper is to present best practices related to the management of a sample learning organization, namely the $\mathrm{R} \& \mathrm{D}$ competence center established by Gdansk University of Technology and IBM. In this paper, the authors strive to emphasize the mechanisms, procedures and decisions taken during the creation of such a center, which lead to an overall enhancement of the intelligence of learning organizations. This paper will discuss the process of creating a dedicated scientific research unit (competence center) allowing the enhancement of organizational intelligence. Particular emphasis was placed on the processes of combining the knowledge and expertise of the university staff with that of the business entities cooperating within joint research and development projects. The final part presents an example of such a project. The authors try to prove that the establishment of such a competence center (hereinafter referred to as CAS, Center of Advanced Studies) allows for the development of the knowledge of all the cooperating entities thereby improving the quality and effectiveness of the implemented processes (projects), which leads to an overall increase in knowledge and enhances the intelligence of the entire organization.

The experience of the authors in carrying out several research and development projects leads to the conclusion that building an open collaboration environment for scientists and business representatives within the framework of joint projects could simply be an effective solution. Hence, CAS at Gdansk University of Technology undertakes the mission to build, maintain and develop an environment conducive to the exchange of experiences between academic staff and business representatives. The following chapter shows that the strength of CAS, as a typical learning organization, are the teams consisting of experts related to the higher education institution, as well as highly qualified professionals from companies cooperating with CAS. It should be noted that such a team not only continues to learn, but also all its actions are directed at increasing the level of organizational knowledge of other organizations.

\section{The Center of Advanced Studies as an example of the enhancement of the intelligence of a learning organization}

The center presented in this paper is the result of cooperation between Gdansk University of Technology (in particular the Department of Information Technology Management) and IBM Poland. After the success of some joint projects, the cooperation was based on formal solutions used by IBM in the world. The first was the University Competence Center (pol. Uniwersyteckie Centrum Kompetencyjne), which was devoted to the development of one particular technology (in this case it was IBM Rational Team Concert).

In 2013 a decision was made to expand the cooperation through the establishment of the Center for Advanced Studies (CAS), which is a higher form of cooperation between IBM and the academic environment, and which became a center of research and development enabling the implementation of joint projects.

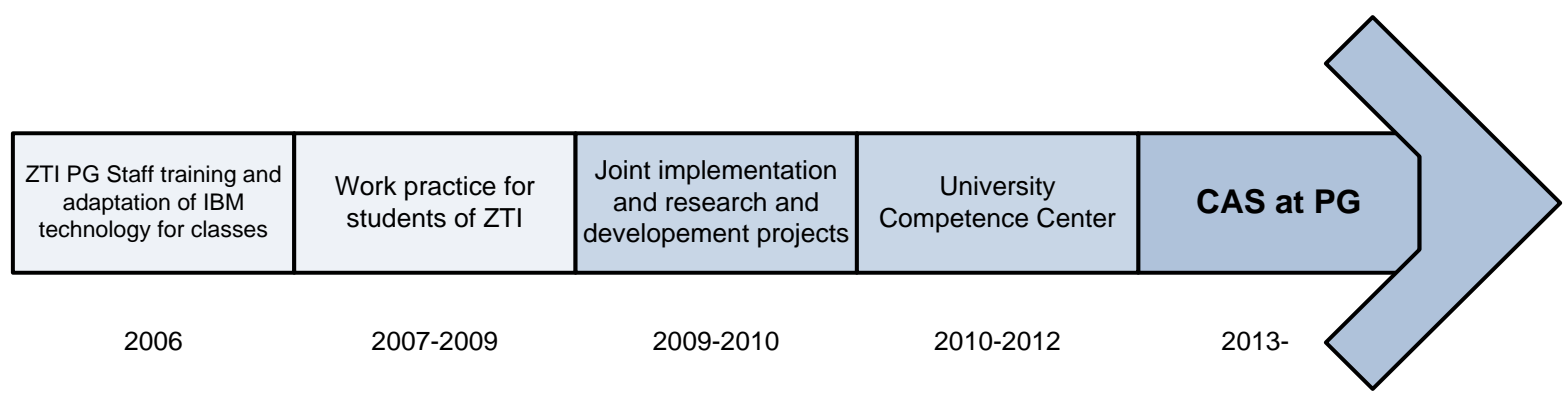

Figure 1. The establishment of CAS - the cooperation development process between the university and the company 
The agreement between IBM and Gdansk University of Technology regarding the appointment of the Center for Advanced Studies resulted in a number of strategic and administrative actions - both on the part of IBM Poland, as well as on the part of Gdansk University of Technology. In effect, CAS was included in the organizational structure of the University. The process of developing the cooperation between the partners which led to the establishment of an independent research and development entity is presented below.

The authors believe that competence centers are typical examples of learning organizations where the knowledge of people who create them is their primary resource. The strength and the most important asset of such centers is a team whose members possess relevant competence in a given area. In the case discussed in this paper, this mainly refers to expertise in the application of methods and tools for IT project management.

Organizations such as CAS, created by IBM around the world, have a higher degree of organization than the Competence Center. Thus the assumption here is that they should also provide other (higher) standards of knowledge management. In organizations such as CAS, the expertise is managed not only on the basis of a team affiliated to a given center, but the aim is to create conditions allowing the implementation of large-scale projects carried out for external partners. This in turn requires the appropriate expertise (and thus knowledge), which sometimes should also be obtained from the environment.

Hence, the location of CAS, at universities, provides access to specialists in various fields of science (among them students, postgraduate students and staff). As a result, during a project, it is possible to use a wide range of expertise (e.g. acquired from many university faculties), which reduces the risk involved in project work and provides easy access to regular consultations regarding any conducted activities, decisions made, etc.

It is also incredibly important to ensure the proper business functioning of organizations such as CAS. The implemented $R \& D$ projects cannot be detached from the reality of the market, therefore CAS requires the existence of business partners (i.e. cooperating companies), so that CAS can focus only on those projects which meet the real needs of the market. Consequently, and seemingly crucial to enhancing the intelligence of the organization, employees of commercial companies become members of project teams (or external consultants - depending on the needs). This in turn allows for the creation of a dynamic structure of the organization, relevant to the current challenges, and thus provides conditions for the increase in knowledge of all the cooperating parties (employees of companies acquire knowledge from university staff and vice versa). The diagram showing how the discussed organization, CAS, functions is presented below in Figure 2.

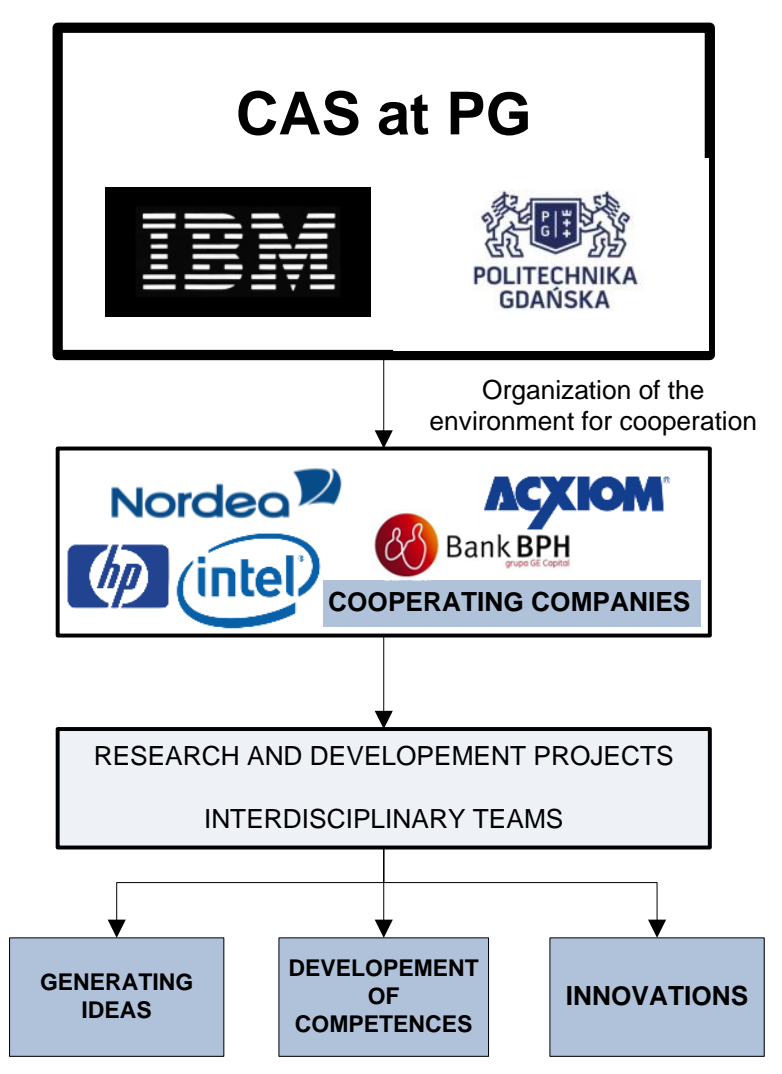

Figure 2. Diagram of how CAS functions 
As the above analysis reveals, CAS is a learning organization which integrates a university with business entities. Due to the expected synergy and the access to highly skilled professionals from companies and experts from a university, it is possible to enhance the organizational intelligence in order to better manage business processes (in effect, research and development projects). Nonetheless, to use this synergy in the proper manner, it becomes necessary to provide the adequate organizational and administrative environment. Hence, best practices for the operation of CAS at Gdańsk University of Technology, which were developed and designed by the founders of the organization, are presented below.

\subsection{CAS as an organization based on projects and expertise}

Competence centers and especially their specific varieties, such as the Center for Advanced Studies discussed in this paper, by their nature require a specific organizational structure. The creators of CAS at Gdansk University of Technology abandoned typical structures for the benefit of a structure based on projects. Hence (as shown in Figure 3 below) it was necessary to select only the owners of the main processes (reporting to one person the coordinator of the entire project portfolio). Such an approach is necessary to enhance the intelligence of an organization and it is virtually unattainable in typical hierarchical organizations. It was agreed that within the major processes the individual owners (leaders) had complete freedom in the selection of management methods and team members and in determining the working conditions of individuals. This was necessary due to the nature of the implemented projects - some of them require classical, others agile approaches in management. Some require a few people, others involve entire business entities (e.g. a city hall). A structure based on projects is so flexible that it can take into account the diversity of the cooperating actors, their internal procedures or their limitations. The training process (associated with the development of the employees, and thus the whole organization) is a separate process, additional to the processes of project implementation, and it is subordinate only to the head of the project portfolio. The responsibility for the training process is dual - it is also based on projects and it applies to both training projects increasing the competence of the CAS employees, as well as to projects provided for people interested in cooperation with the center (students, university staff, representatives of companies), which provides mutual benefits in the form of the development of the existing knowledge and the enhancing of general intelligence across an organization based on projects.

It should be noted that within the individual processes of CAS at Gdansk University of Technology, it was assumed that projects will be implemented within four main thematic areas. This is a consequence of previous cooperation with business entities. These thematic areas implemented by CAS include (Bergstom and Reberg, 2003; Wiegers, 2003):

- the development of city management systems in the spirit of Smarter Planet (Intelligent Operating Center),

- the creation of mobile applications for IBM Rational products,

- the creation of referential models supporting the software development cycle - the Rational products,

- Software Development Environments.

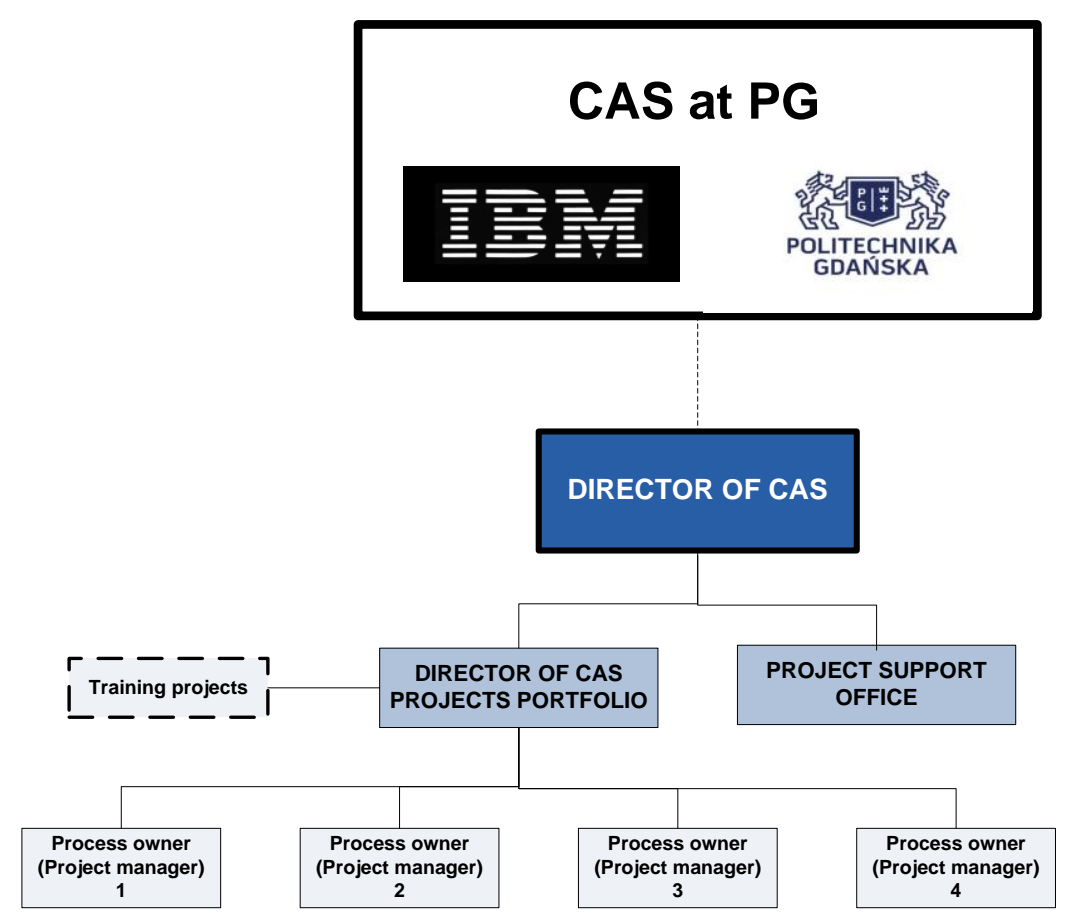

Figure 3. Organizational structure of CAS 
Each of these research topics is now a separate project. Therefore, the organizational structure of CAS at Gdansk University of Technology must be based on project activity resulting from these themes. In order to eliminate any formal and administrative problems, a support office for all projects was established, which acts as an operating center for the implemented projects. This approach was adapted from formal project management methods, according to the assumptions of adaptive project management (Ziółkowski and Sitek, 2011).

\subsection{CAS as an organization based on interdisciplinary teams}

In R\&D organizations, such as CAS at Gdańsk University of Technology, the key responsibility lies on the people involved in them. The second important element is the infrastructure facilitating the gathering and processing of knowledge. Hence, the governance structure specifying the hierarchy, scope of responsibilities, as well as procedures and technologies to properly use the accumulated knowledge is immensely important. In accordance with the rules of intellectual capital management (human capital + infrastructure), in the first year of the functioning of CAS, the idea was to concentrate on ensuring an adequate division of competence and on building an infrastructure supporting the management of the knowledge obtained via projects completed by CAS. In this way, the continuous measurement and development of the entire intellectual capital of CAS will be possible, which is a key factor in the success and development of the center. With respect to the previously presented structure, the persons/roles can be identified as permanent or as those that participate in conducting research (Figure 4).

Such a structure, viewed in the context of enhancing the intelligence of an organization, determined the initial scope of responsibilities of individual members. The characteristic features of particular roles, shown in Table 1, were specified on the basis of this.

This summary takes into account the constant improvement of the quality of knowledge possessed by CAS. The authors assume that in addition to the permanent persons, it is necessary to 'acquire' knowledge from outside, i.e. companies cooperating with CAS.

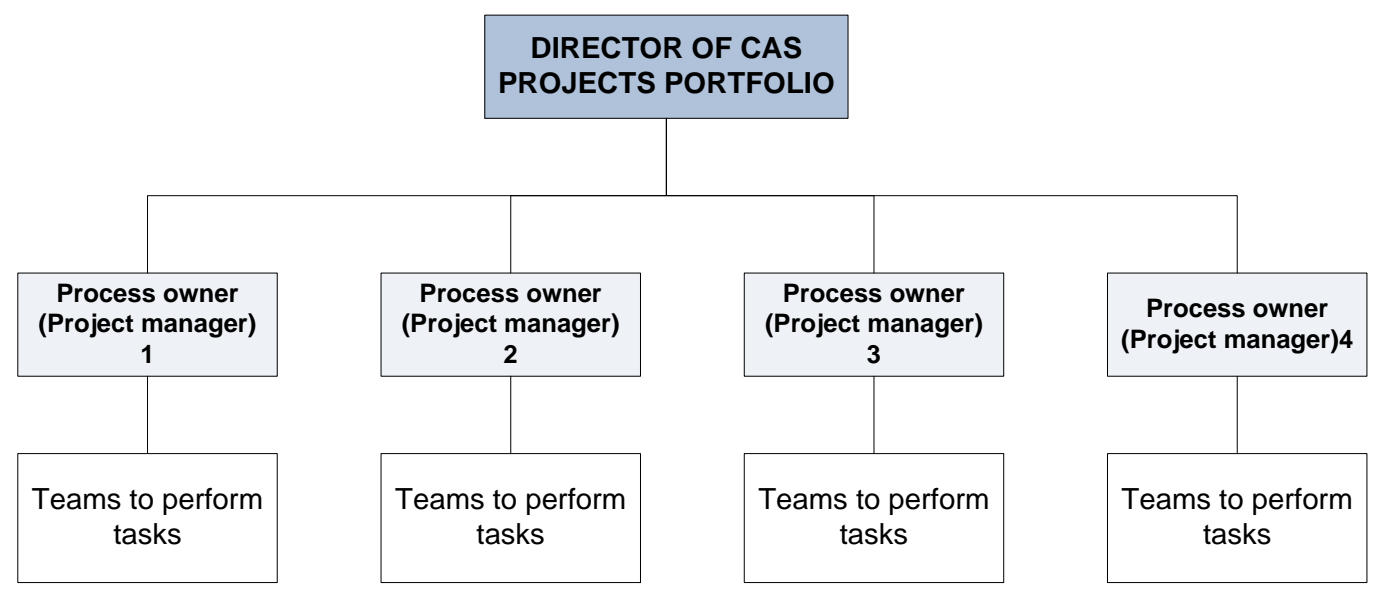

Figure 4. Role structure of members involved in projects implemented by CAS

Table 1

Characteristic features and scope of responsibilities of particular roles in CAS at Gdańsk University of Technology

\begin{tabular}{|c|c|c|}
\hline ROLE/PERSON & $\begin{array}{c}\text { FEATURES/ } \\
\text { REPRESENTATIVES }\end{array}$ & SCOPE OF RESPONSIBILITIES \\
\hline $\begin{array}{l}\text { PERMANENT } \\
\text { PERSONS }\end{array}$ & $\begin{array}{l}\text { These are permanent workers of CAS selected from } \\
\text { Gdansk University of Technology and IBM employees. } \\
\text { They are experienced in managing research and } \\
\text { development projects as well as in carrying out IT projects } \\
\text { (preferably regarding the development and implementation } \\
\text { of IT systems). They should possess basic knowledge of } \\
\text { Rational products and should be familiar with IBM's } \\
\text { business philosophy. }\end{array}$ & $\begin{array}{l}\text { - } \\
\text { pupervision of the fundamental CAS } \\
\text { - } \quad \text { The organization of teams } \\
\text { Reporting and setting operational } \\
\text { objectives for the teams } \\
\text { Concluding tasks performed by } \\
\text { subordinate teams }\end{array}$ \\
\hline $\begin{array}{l}\text { PARTICIPATING } \\
\text { PERSONS (co-workers) }\end{array}$ & $\begin{array}{l}\text { These are all people interested in improving their skills } \\
\text { and experience through the execution of the center's tasks. } \\
\text { These may include representatives of companies } \\
\text { cooperating with CAS as well as employees of Gdańsk } \\
\text { University of Technology and students interested in } \\
\text { expanding their horizons. }\end{array}$ & $\begin{array}{l}\text { - Implementation of the R\&D tasks } \\
\text { Participation in training sessions } \\
\text { conducted by CAS and IBM } \\
\text { - } \quad \text { Certification in specific tools } \\
\text { The use/implementation of } \\
\text { technologies used for educational } \\
\text { purposes in CAS }\end{array}$ \\
\hline
\end{tabular}




\subsection{CAS as an organization of innovative knowledge}

The final feature of CAS, typical of learning organizations, is the need for innovation management. The research areas presented earlier require continuous, consistent and formal management of their knowledge, but in many cases they also require resorting to external knowledge. Projects involving software development or the implementation of intelligent systems for cities absorb knowledge from several areas simultaneously - and that knowledge concerns not only the fields of management and computer science, but also psychology, sociology, and at times chemistry and land surveying. Combining these disciplines in one project results in the emergence of new, unique knowledge. The interdisciplinary character contributes to faster and more efficient solving of specific business problems. The authors discovered this during the first joint venture of CAS, associated with the development of project management software. Hence, the following chapter will present the project which utilized the advantages of 'enhanced' organization intelligence in a team composed of representatives of academia, the IT industry and domain experts.

\section{Management of project experience on the basis of the SOEKS concept - the first project of CAS}

The previous chapter presented the basic premises which underpin the concept of Competence Centers, in particular CAS. If this may still not be sufficiently convincing evidence that these are learning organizations established in order to enhance their own intelligence, then it will be worth quoting two other definitions which were not mentioned before, saying that this type of entity (CAS webpage, 2014):

- acquires and implements knowledge into structures, products, processes and organizational practices (and whenever possible).

- $\quad$ possesses maximum flexibility; routines, habits and stereotypes do not substitute the dynamic reality.

These definitions describe the current profile of CAS at Gdansk University of Technology very well. They highlight its greatest advantages arising directly from the fact that it is a very young entity. The fact that its principles are based on its own statute, and that it is formed by a small group of involved people contributes to great flexibility (unfortunately such a foreign concept to university structures). All actions are performed on the basis of available expertise (i.e. the knowledge of the organization), while processes and structures are chosen or established according to needs. The best example of this practice is the first project launched by CAS, described in this chapter.

The objectives of the project, with the working title 'a solution for project experience management', arose from the observations and experience of the authors in the area of IT project management. This domain is one of the biggest challenges of today's IT organizations. All of these organizations run several or even more different projects each year. Unfortunately, many of them fail.
Due to the fact that every IT project is a unique action (process) by definition, it would seem that decisions taken by managers are different every time. Although generally this is true, the observations of dozens of projects carried out by members of CAS made it possible to identify some common elements (areas) within which managers make decisions. A common denominator can thus be found among different projects and, consequently, a general model of the so-called 'IT project environment' can be specified, in which the authors include the: project team, client, tools and methods used during the project. Within this environment, there is also expertise, be it more or less imperfect, which supports the process of project implementation. It comes from a variety of sources external and internal. Therefore it has some imperfections, such as the fact that it is rarely complete and often imprecise (Orłowski and Sitek, 2010).

A few questions arise. Can decisions made in one project be important for subsequent projects? Is it possible to collect such knowledge from available sources so as to provide an objective and reliable decision support for a project manager - decision maker? Is it possible to build a smart solution, supporting decision makers in IT projects, based on such knowledge?

These questions contributed to the fact that members of CAS undertook research and initiated the first project to be implemented within the framework of the competence center. The project aims at building a solution for the management of project experience based on the so-called SOEKS concept.

What is SOEKS? In the simplest terms, it is a concept which indicates that the implementation of decision support rarely has a reason to exist if the construction of a classical and objective knowledge base is assumed (e.g. rule-based). What seems to be the key issue instead, is the experience of project managers. Given that the measure of the success of an IT project is for it to be implemented in the context of classical boundary conditions such as schedule, budget and scope, then the final evaluation of the impact of decisions on this success can be discussed. By possessing identified variables and knowing what decisions were made under these conditions, regarding the selection of project management methods, such experiences can be used in future projects. All project decisions can be considered as experience on which project managers taking decisions on new projects can base their decisions. Indeed, if a project manager is able to assess whether, with a specified level of project team maturity and client maturity and with a particular applied method of project management, the project was a success, then the decision will be recognized as a valuable experience for managers whose teams and clients exhibit similar levels of maturity.

The concept of SOEKS (The Set of Experience Knowledge Structure) was developed precisely for problems of a similar nature. It can be described as a tool based on experience which uses so-called decision-making events, namely all the individual decisions which occur during the execution of a given project and for which it is possible to clearly describe the premises as well as the conclusion of the adopted rules on the basis of which 


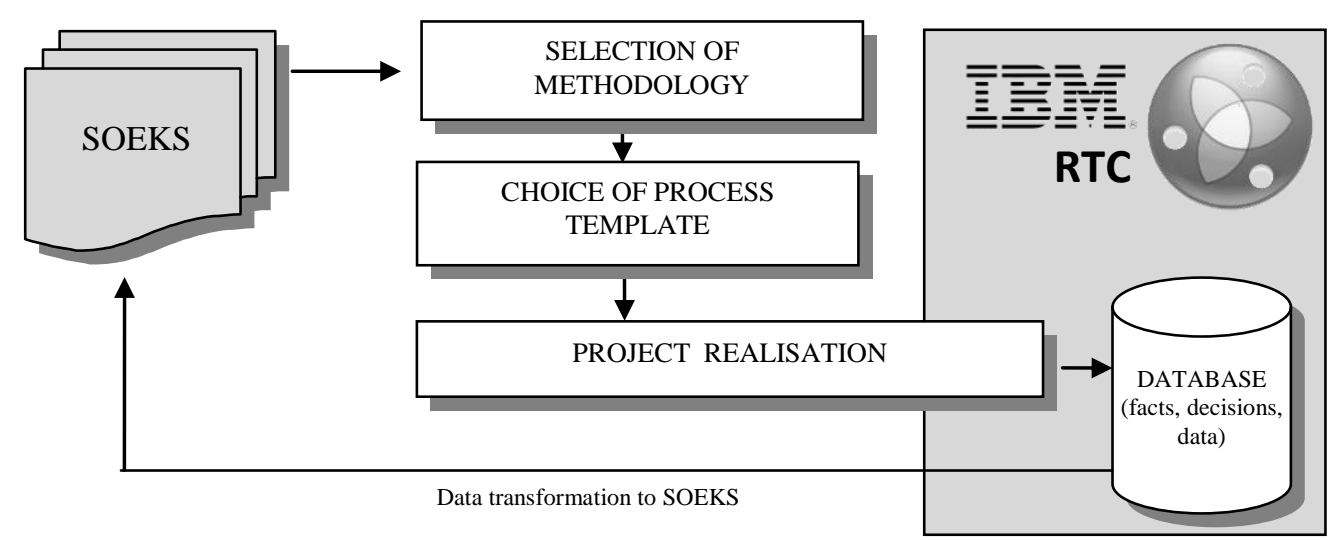

Figure 5. Concept of operation (information flow) in the RTC-SOEKS system

a decision was made. The SOEKS idea was thoroughly described in 2007, in the doctoral thesis of Cesar Sanin. $\mathrm{PhD}$ (Sanin and Szczerbicki, 2009) and is part of the research on the so-called Knowledge Supply Chain System, carried out at the University of Newcastle (Australia). The merit of SOEKS is confirmed by the number of times this form of recording experience has been applied in various fields of human activity, including medicine (the gathering and management of medical diagnoses, as support for everyday hospital practice) and transport (the analysis and selection of optimal rail routes).

The first project implemented by CAS is meant, first of all, to use SOEKS to support a crucial decision of the IT project manager - the selection of methodology for conducting this project. The set of available methodologies will be closed at the initial stage. Possible choices are: PRINCE2 (heavy methodology), RUP (heavy methodology), Agile (light methodology) or Scrum (light methodology). The choice of methodology will depend on the four input values describing the project environment (Ziółkowski and Sitek, 2013):

- project team maturity,

- (dis)organization of the project (so-called entropy),

- client maturity,

- client suitability for the specific nature of the project.

The product of the project is to be a tool which, by being made available to the community of project managers, will allow for the gathering of their experiences, and (more importantly) their evaluations of their decisions. Each decision, written in a formalized manner, will enrich the experience base, which will be available for each subsequent decision-maker. The aforementioned tool is planned as a plug-in to a dedicated programme - IBM Rational Team Concert (RTC), which, on the one hand, makes it possible to record all events (decisions) in an implemented project; and on the other hand, it possesses process templates customized for projects implemented according to different methodologies (Kruchten, 2004; PMI, 2008; PRINCE2, 2009).

The purpose of this paper is not to describe the technical aspects of the project, thus its idea is shown in Figure 5 in very general terms.

\section{Summary and conclusions}

The paper is description of the idea of CAS - Center of Advance Studies. CAS is research unit established on Gdańsk University of Technology, which mission is to build, maintain and develop an environment conducive to the exchange of experiences between academic staff and business representatives. CAS is ideal example of the learning organization. It is supposed to be using its collective intelligence in order to enhance the knowledge of different IT organizations - partners of CAS. It is the thesis that authors - co-creators of this organization - are constantly trying to prove by their daily work on projects. However this is not only running projects but also trying to record and store every piece of information and/or knowledge which may be useful resource for re-use in further jobs.

The paper describes the effect of such process gathering and sharing knowledge achieved by CAS. On the one hand, the concept of recording experiences in a formal way (SOEKS) was applied, obtaining knowledge from the research team cooperating within Gdansk University of Technology. On the other, it was necessary to create a development team associated with software development (students and PhD students of IT faculties) to finally obtain experts in the field of project management who can provide appropriate rules to be implemented in the tool.

The first effects of CAS activities undoubtedly give hope to overcome the barriers, which struggled so far 'classic' initiatives of cooperation between universities and business environment. Legal and organizational determinants are positive. There is also a good climate in Poland for such kind of initiatives - the institutions of the European Union responsible for granting funds for research strongly promote such cooperation. However, to make the following SWOT analysis completed we must pay attention also to the weaknesses and threats of this institution and projects within its framework.

Certainly, the main obstacles are related to the money. Due to the fact that CAS in Gdansk is also a brand new concept for IBM Poland, there is no clear business model that specifies two basic issues. First - IBM does not have a dedicated budget for direct CAS support. The second - the 
acquisition of knowledge from IBM and access to the latest technology is still far from ideal. It may seem strange, but the project management environment RTC (described in this paper) does not have support from IBM Poland. This means that there is no such support for CAS. Therefore for now, contacts with other IBM units in the world are required, which is sometimes quite difficult. These two issues will need to be clarifies in the first place.

To summarize, the following question can be asked: is CAS activities profitable? Since the project is at its early stage, it is difficult to talk about specific and financially measurable results of the research. Nonetheless, despite such its early stage, it can already be observed that without CAS, obtaining the relevant competencies to carry out this kind of project would be impossible. The best evidence of this is the fact that the development team consults all its actions with an IBM representative on a regular basis and solves problems.

One thing can be observed - CAS acts faster than traditional cooperation between university and company would act. Without its dynamic structure and the sharing of knowledge in the way as described above, some of the problems would probably be solved with much bigger effort. Maybe without consultations, but this would take a lot longer. Thus, from the point of view of the efficiency of project processes or project management processes, as well as the minimization of risk, the authors recognize the first advantages of the way the developed concept of CAS at Gdansk University of Technology functioning.

A competence center is certainly a form of intelligent organization. Thanks to its structure, it achieves a significant synergy, which results in the efficiency of research work. It should also be noted that CAS focuses on projects devoted to supporting other organizations (IT, in particular). A unique relationship takes place - an organization enhances its intelligence so that other entities could enhance theirs too.

\section{References}

1. Bass, L., Clements, P., \& Kazman, R. (2003). Software Architecture in Practice. Boston: Addison-Wesley.

2. Bergstom, S., \& Reberg, L.(2003). Adopting the Rational Unified Process: Success with the RUP. Boston: Addison-Wesley Professional.

3. CAS webpage. Retrieved August 4, 2014, from http://cas.pg.edu.pl

4. Kruchten, P. (2004). The Rational Unified Process: an introduction. Boston: Addison-Wesley.

5. Madej, Z. (2006). Gospodarka oparta na wiedzy wkracza w świat paradygmatów. In E. Frejtag-Mika (ed.), Teoria $i$ praktyka ekonomii a konkurencyjność gospodarowania, 15-16. Warszawa: Difin.

6. Obłój, K. (1985). Strategia przetrwania organizacji. Warszawa: PWN.

7. Organization for Economic Co-operation and Development (1996). The Knowledge-Based Economy - report, Paris.

8. Orłowski, C., \& Sitek, T. (2010). Supporting Management Decisions with Intelligent Mechanisms of Obtaining and Processing Knowledge. In Lecture Notes In Computer Science, No 6277, 571-580. Berlin: Springer Verlag. http://dx.doi.org/10.1007/978-3-642-15390-7_59

9. Parth, F., \& Snyder, C. (2007). Introduction to IT Project Management. Vienna: Management Concepts.

10. PMI (2008). A Guide to the Project Management Body of Knowledge ( $4^{\text {th }}$ edition).

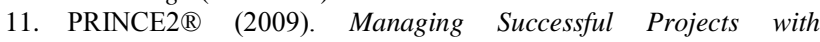
PRINCE2 ${ }^{\circledR}$.
12. Sanin, C., \& Szczerbicki, E. (2009). Experience-based Knowledge Representation: SOEKS. In Cybernetics and Systems: An International Journal, 40, 99-122. http://dx.doi.org/10.1080/01969720802633149

13. Wiegers, K. E. (2003). Software requirements (2 th edition). Washington: Microsoft Press.

14. Zgrzywa-Ziemiak, A., \& Kamiński, R. (2009). Rozwój zdolności uczenia się przedsiębiorstwa. Warszawa: Difin.

15. Ziółkowski, A., \& Sitek, T. (2013). Projekt-czynnik-decyzja. Badanie czynników decyzyjnych $w$ projektach informatycznych $i$ ich wpływu na powodzenie projektów. In Z. Szyjewski, K. Muszyńska (eds.). Zarządzanie projektami $i$ modelowanie procesów, 49-61. Warszawa: Rada Naukowa Polskiego Towarzystwa Informatycznego.

T. Sitek, A. Ziółkowski

Besimokančios organizacijos vystymas pasitelkiant kompetencijos centrus

Santrauka

Pagrindinis straipsnio tikslas - pristatyti šiuolaikines informaciniu technologijų organizacijos valdymo tendencijas, ypatingą dèmesị skiriant kompetencijos centrams. Centrai - specialūs tyrimų ir vystymosi padaliniai, inicijuojantys ir realizuojantys projektus bei prisidedantys prie produktų vystymosi.

Ilgą laiką kompetencijos centrai koncentravosi universitetuose. Tai leisdavo derinti IT (informacinių technologijų) organizacijose sukurtas žinias su idejjomis, kurios vystomos mokslininkų, dirbančių universitetuose.

IT kompanijose yra besimokančios organizacijos, prisidedančios prie ịvairių vystymosi procesų. Tai reiškia, jog tokių centrų organizacinè struktūra ir veiklos pobūdis kinta priklausomai nuo rinkos vystymosi ir technologijų poreikio bei įtakos.

Kompetencijos centrai yra toks organizacijos tipas, kurioje tipiška struktūra keičiama projektinès organizacijos struktūra (aiškūs projektai, projektu vadovai, projektinès komandos). Kompetencijos centrų valdymas ypač remiasi organizaciniu mokymusi, šio proceso metu ypač svarbūs tampa žinių ir patirčių valdymas. Straipsnyje pateikiamos ¡žvalgos apie tokių organizacijų valdymą, akcentuojant, kad projektai gali adaptuoti savo struktūrą prikausomai nuo projekto.

Anksčiau minètų klausimu sprendimai iliustruojami remiantis IBM Pažangos centro atveju (IBM CAS). Šis centras, kaip tyrimų vienetas, buvo ikkurtas Gdansko technologijos universitete. Centro misija - sukurti, palaikyti, vystyti aplinką, palankią verslo ir mokslo bendradarbiavimui. Kita vertus, šis centras - puikus besimokančios organizacijos pavyzdys, kai kolektyvinè inteligencija panaudojama įveiklinant įvairių IT organizacijų žinias.

Straipsni sudaro trys dalys. Pirmojoje dalyje analizuojamas kompetencijos centrų kaip specifinių žinių organizacijų fenomenas bei vystymosi galimybès. Antrojoje dalyje pristatomas IBM CAS Gdansko technologijos universitete kaip besimokančios organizacijos atvejis, kurioje vyksta žinių valdymo procesai, šie procesai labai svarbūs vystant visos organizacijos inteligenciją. Kadangi CAS kaip organizacija veikia projektiniu principu, trečiojoje dalyje pristatomas vienas iš pagrindinių centro projektų, kuris stipriai sieja žinių ir patirties valdymo problemas.

Pirmojoje dalyje fiksuojama aiški tendencija universitetuose steigti ir pozicionuoti kompetencijos centrus universitetuose, todè šie centrai igauna tipiškų mokslinių tyrimų centrų charakteristikas: pagrindinis centrų tikslas tampa taip paremti mokymo ir mokymosi procesus, kad būtụ parengti kompetentingi konkrečių i̇monių darbuotojai. Bendri projektai, kuriu metu imonès žinios derinamos su teoriniais konceptais, didina visų projekto dalyvių žinių tezaurą. Sujungiant žinias galima padidinti bendrą organizacijos inteligencijos lygị (žinios, igūdžiai, patirtis), kalbant apie organizaciją turima galvoje ne tik įmonių darbuotojus, bet ir universiteto akademinis personalas, studentai, doktorantai ir pan. Ši dalis baigiama išvada, kad kompetencijų centrai gali padidinti įmonès inteligencijos augimą.

Kitoje dalyje atskleidžia IBM CAS procesus. Straipsnio autoriai atskleidžia specifini kompetencijos centrų vaidmeni, susijusį su organizacijos inteligencijos vystymu ir pateikia naujas tendencijas, susijusias su IT organizacijų evoliucija - nuo hierarchinès iki projektinès struktūros. Straipsnyje pastebima, kad kaip tik tada, kai centrai turi technologinius projektus, jie tipines valdymo struktūras pakeičia projektinėmis struktūromis: skyrių vadovai pakeičiami projekto vadovais; 
tipinès pozicijos keičiamos komandomis, realizuojančiomis projektą. Straipsnyje taip pat akcentuojama, kaip projekto realizavimo metu vyksta praktinių ir mokslinių žinių kaita. Taip pat atkreipiamas dèmesys, jog CAS kaip tipinè besimokanti organizacija rekalauja tam tikrų valdymo inovacijų, ypač aptinkant ir atsirenkant išorines žinias. Pavyzdžiui, projektuose, kurie orientuoti i išmaniųų sistemų mieste diegimą, reikalauja absorbuoti žinias iš icvairių sričių vienu metu - ne tik iš vadybos ir informatikos, bet ir psichologijos, sociologijos, kartais chemijos ar kraštotvarkos. Kombinuojant šių disciplinų žinias, siekiant vieno projekto rezultatų, leidžia pasiekti naujų, unikalių žinių. Tarpdisciplininis pobūdis prisideda prie greitesnio ir efektyvesnio specifinių verslo problemu sprendimo.

Trečioji straipsnio dalis - praktine ir fokusuojasi i patirtis, kurias igijo CAS, realizuojant vieną iš projektų. Projekto metu buvo naudota formali žinių ir patirties aprašymo sistema (angl.SOEKS). Atsižvelgiant ị šią sistemą, buvo pasirinkta atitinkama tyrimo metodologija. Pradiniame etape buvo analizuojamos įvairios metodologijos: PRINCE2 („kietoji” metodologija), RUP („kietoji” metodologija), XP (,lengvoji” metodologija), Scrum (,lengvoji” metodologija). Metodologijų pasirinkimas priklausė nuo keturiu svarbiu aspektų: projekto komandos branda, projekto (de-)organizacija (vadinamoji entropija), klientų branda, klientu poreikiu atitikimas projekto pobūdžiui. Straipsnyje taip pat pateikiama, kaip vyko žinių pasiketimas projekto metu, taip pat aprašytas žinių sklaidos efektas.
Straipsnio pabaigoje daroma išvada, kad kompetencijos centras yra tam tikra inteligentiškos organizacijos forma. Kadangi centras turi tinkamą struktūrą - pasiekia svarbią sinergiją, kuri atsispindi tyrimo rezultatų efektyvume. Taip pat pažymima, jog centras koncentruojasi i projektus, kurie skirti padèti kitoms organizacijoma, ypač IT. Ivyksta unikali sąveika - centras didina savo inteligenciją, o tuo pačiu didèja ir kitų struktūrinių vienetų inteligencija.

Reikšminiai žodžiai: žinių valdymas, projektų valdymas, kompetencijos centrai, IT organizacijos, organizacinis mokymasis.

First received: June, 2014

Accepted for publication: September, 2014 